\title{
Post Pandemic Indonesian Regional Development Planning, New Normal, New Orientation: The Case of West Java
}

\author{
Satya Laksana ${ }^{1}$
}

Corresponding author. Email: satya.laksana@tasikmalayakab.go.id

Submitted: 2020-11-17 | Accepted: 2021-04-26 | Published: 2021-04-30

\begin{abstract}
Corona Virus Diseases (Covid-19) outbreak has impacted almost all aspects of life including regional development planning in Indonesia. The new regional development planning orientation per se adjusts the new habits of citizens in the new normal era which is well-known as the Internet of Things (IoT) lifestyle. This paper elaborates the post-pandemic development orientation of the West Java Province by answering three problem statements: 1) What is the Government Policy in dealing with the Covid19 pandemic; 2) What is the condition of existing IoT Infrastructure in Regencies and municipalities in West Java Province, and 3) what is the new development orientation of West Java Province based on the existing conditions. By utilizing dataset from the Government's official website and elaborating relevant articles in scientific journals and news in mass media, it discusses intended issues thematically with a deductive approach. The discussion covers the author's outlook of the new development orientation on three sectors: 1) education, 2) infrastructure and 3) bureaucratic reform. Policy implications are discussed.
\end{abstract}

Keywords: regional development orientation; internet of things; post-pandemic

\footnotetext{
${ }^{1}$ Regional Development Planning Agency of Tasikmalaya District, West Java, Indonesia
} 


\section{Post-Pandemic Indonesian Regional Development Planning; New Normal, New Orientation}

Satya Laksana

\section{Introduction}

\subsection{Background of Problem}

Corona virus disease (Covid-19) pandemic has impacted almost all aspects of life. The economy is one of the most impacted as it decreases the demand for goods and services due to supply chain disruption (UN DESA, 2020). It has also disturbed people's social life, such as increasing unemployment, poor households having difficulties affording basic needs, and the emergence of crime (Nugroho, et al 2020). The public sector was also obstructed as the government budget has to be refocused and reallocated for handling covid-19. Refocusing on the budget has consequences for changes to the Government Work Plan (Rencana Kerja Pemerintah /RKP) and Local Government Work Plan (Rencana Kerja Pemerintah Daerah/RKPD) for the 2020 fiscal year as well as shifting the orientation and priorities of the RKP and RKPD in the following years.

In the (post) pandemic era, the (regional) development planning consequentially adapts to the new habits of people's life patterns in the era known as the new normal. Among the new habits are working from home, schooling from home through online distance learning, and online purchasing for household daily needs.

During the pandemic, almost all of the goods and services consumption as can as possible be done from home or what is called the "less physical contact economy" (Dewan TIK Nasional, 2020). Some of these ways of life are predicted to be permanent even after the pandemic has ended. Thus the post-pandemic regional development orientation should support the economic concept along with the development of industry 4.0. The less physical contact economy and industry 4.0 require internet network connectivity as a communication medium for all things as a single integrated system (Internet of Things / IoT).

However, the implementation of the Internet of Things / IoT in some regions, including in West Java Province, faces challenges with limited infrastructure and human resource capacity. Kompas Daily in July 2020 reviewed that the Covid-19 Pandemic changed consumer behavior and opened wider online business opportunities. However, the majority of Micro Small Medium Enterprise (MSME) players had not been able to take advantage of the opportunities, especially regarding limited access and digital literacy (Theodora, et all, 2020). Likewise with the new normal in educational conducts. The biggest challenge in implementing distance learning, as recognized by the head of the West Java Provincial Education Office, is internet facilities (“pembelajaran jarak jauh”, 2020).

\subsection{The problems (research/paper questions)}

This paper elaborates the post-pandemic regional development planning orientation in Indonesia, within the context of the West Java Province. It discusses three critical problem statements based on the background: 1) What is the Government Policy in dealing with the Covid-19 Pandemic; 2) What is the condition of the existing telecommunication 
infrastructure and internet network in the regencies/cities in West Java Province, which is one of the factors supporting activities during the pandemic period; and 3) What is the new orientations of regional development planning in West Java Province based on the existing conditions.

The answers to the three questions above are very crucial. It is predicted that the public needs orientation in the post-pandemic era will not only the provision of rudimentary infrastructures such as roads, bridges, drinking water networks, and educational facilities; but will turn to the development of telecommunications infrastructure. It is hoped that this paper can be useful in enriching references/literature in post-pandemic economic recovery efforts in the aspects of regional development planning, especially in West Java province.

\subsection{Logical Framework}

This paper proposes a new orientation for regional development in West Java Province due to the Covid-19 pandemic. This paper does not yet discuss regional development priorities. Prioritization needs to take standard procedures preceded by the determination of strategic issues in an integrated manner among development stakeholders as mandated by Law number 25 of 2004 concerning the National Development Planning System. Thus, this paper consists only an outlook from a professional planner.

\section{Methods/Methodology}

This paper is a projection or prediction of future conditions using existing data. It employs an analytical descriptive method, which is to provide an overview of the issues through the data that has been collected as it is (Sugiono, 2009; 29).

It utilizes dataset downloaded from the government official website then transform them statistically into informative bar charts, pie charts, and tables. It also elaborates analysis from scientific journals, seminar proceedings, as well as actual and relevant news collections in the mass media. Hereinafter, it discusses intended issues thematically using the deductive approach. As a personal notion, this paper is open to correction to be developed in further discussion.

\section{Results, Analysis, and Discussions}

\subsection{The Government Policy upon Covid-19 Pandemic Outberak}

Government policy in dealing with the Covid-19 pandemic begins with Presidential Decree number 7 of 2020 concerning the Task Force for the Acceleration of controlling Corona Virus Disease 2019 (Covid-19). This was followed by Presidential Decree Number 12 concerning the Designation of Non-Natural Disasters for the Covid-19 outbreak as a National Disaster. In general, the strategy taken by the Indonesian Government was not to choose total area lockdown but to implement a Large-Scale Social Restriction (Pembatasan Sosial Berskala Besar /PSBB) policy which was implemented in areas run into the serious spread of the virus based on Government Regulation number 21 of 2020.

Government policy in the education sector through Minister of Education and Culture Circular Letter (SE MenDikBud) Number 4 of 2020 stipulates, among others: 1) schooling from home 2) National Examination (Ujian Nasional/UN) be canceled including Skills 
Competency Test 3) Admission of New Students (Penerimaan Peserta Didik Baru/PPDB) be conducted online, and 4) school operational assistance funds (Bantuan Operasional Sekolah/BOS) can be used for procurement goods in pandemic prevention. The substance of all government policies is to stop the spread of the virus with implementing health protocols and the principle of social distancing with restrictions on social activities that cause crowds.

Social activities restriction policies, either Lockdown or PSBB, emit negative effects on the order of life, especially in the economic, social, and cultural sectors (Pradesha, et al, 2020). However, social restrictions during the pandemic gave a blessing in disguise on the environment and the improvement of the global climate (Verma \& Parkash, 2020), on the increase of effectiveness and efficiency of bureaucratic services in Indonesia (Taufik \& Warsono, 2020), and on the adoption and technological interventions in all aspects of human life (Wahyudi, et al, 2020).

Before the pandemic outbreak, Indonesia had determined Industry 4.0 as one of the national development orientation. Industry 4.0 refers to a new stage in the Industrial Revolution that focuses mainly on interconnectivity, automation, machine learning, and real-time data.

During the pandemic, Information Communication Technology (ICT) that offers interconnection of things has become one of the main solutions in daily activities. The pandemic has accelerated the process of developing the Internet of Things (IoT) in Indonesia. However, IoT requires adequate infrastructure. The existing condition of supporting infrastructure for IoT development in Indonesia, especially in West Java, is discussed in the next section.

\subsection{The West Java Province's Telecomunication Infrastructures Condition}

Telecommunication infrastructures condition discussed in this paper includes 1) electricity infrastructure, 2) cellular phone signals strength, 3) internet signal quality, 4) Base Transceiver Station (BTS), 5) ICT Development Index, and 6) Cyber Security Index (CGI).

1) electricity infrastructure

One of the necessites for humankind activities is energy. Electricity is the main type of energy that supports living, including for activities in the internet and telecommunications networks. The total blackout that occurred on 4 August 2019 gave a lesson about how much human life is dependent on electrical energy.

Due to a failure of the $500 \mathrm{kV}$ transmission in Ungaran, the State Electricity Company (Perusahaan Listrik Negara/PLN) shut down the energy supply for several hours in the DKI Jakarta, West Java, and Banten areas which affected 21 million customers. The cut-off of electrical energy has paralyzed public transportation, telecommunications, water supply, and traffic. In other words, the sustainability of electrical energy supply is crucial for livelihoods in the present and in the future. 


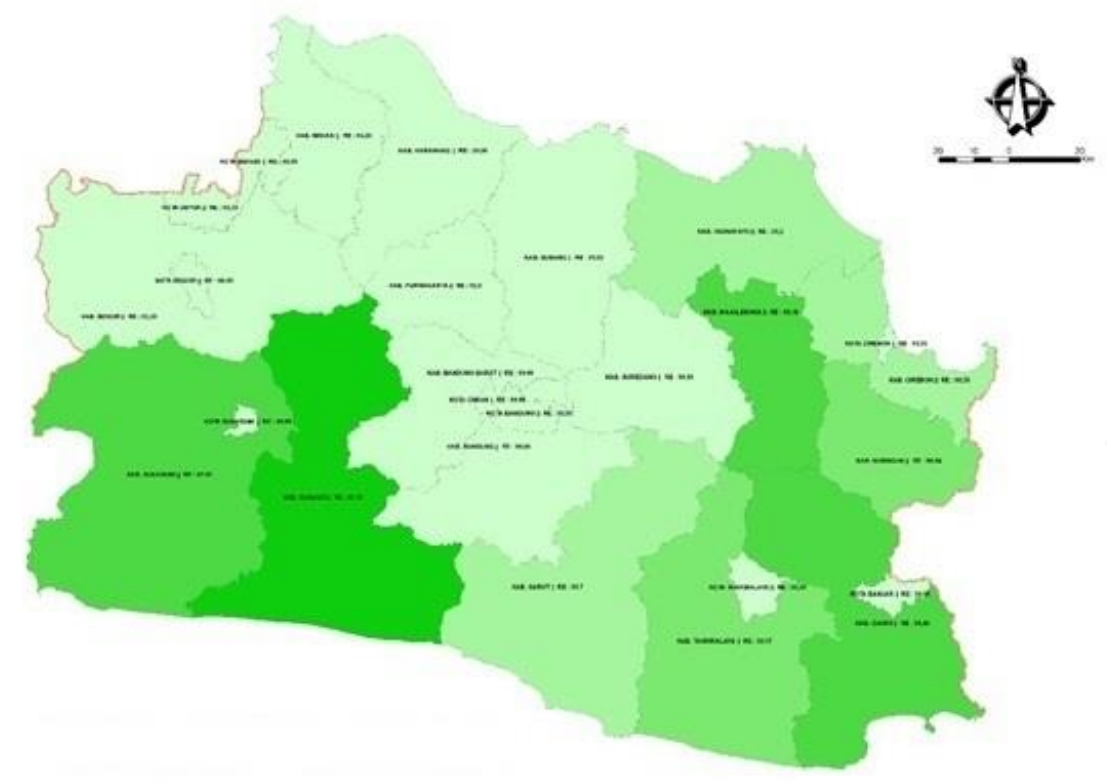

Figure.1 The electricity ratio of regencies/municipalities in West Java in 2018

Source: Dinas ESDM Provinsi Jawa Barat

The electrification ratio of West Java in 2018 was 99.99 percent (esdm.jabarprov.go.id). This figure means that one in ten thousand households in remote areas of West Java (estimated 260,000 households) do not yet have electricity access either from the PLN or from any other sources. In addition, the distribution of electricity infrastructure between northern and southern areas is still unequal. Figure.1 shows the distribution of electrification ratios for districts and municipalities in West Java. Darker colored areas indicate a lower electrification ratio than lighter colored areas.

The electrification ratio in a territory is closely related to the existence of electricity infrastructure. Adequate electricity infrastructure supports the economic activities of the citizen, which in turn increases regional economic growth. A study conducted by Maqin (2014) concluded that electricity infrastructure has a positive correlation with economic growth in districts and cities in West Java. This study bares that although the condition of West Java's electricity infrastructure nowadays shows better than in previous years, the available electricity supply has not been able to keep up with the demand, especially from productive sectors.

The electric power supply is a main production factor for the industrial sector. The manufacturing industry generates a significant contribution to the Gross Domestic Product (GDP) of a region. The manufacturing industry that tends to be scattered in the northern areas elucidates the West Java economic disparities between the north and the south.

2) Cellular phone signals strength

In 2018 more than a thousand villages in West Java were still served with weak cell phone signals (Figure.2). In fact, around seventeen villages in West Java have not been covered by cellphone signals at all. The seventeen villages are spread across nine regencies, mostly in 
Tasikmalaya and Cianjur Regencies, each with three villages (Table.1). Even though the majority of villages in West Java covered by cellular telephone signal, in several locations in the village there are still areas without cellphone signal or blankspot (Virgana, 2018).

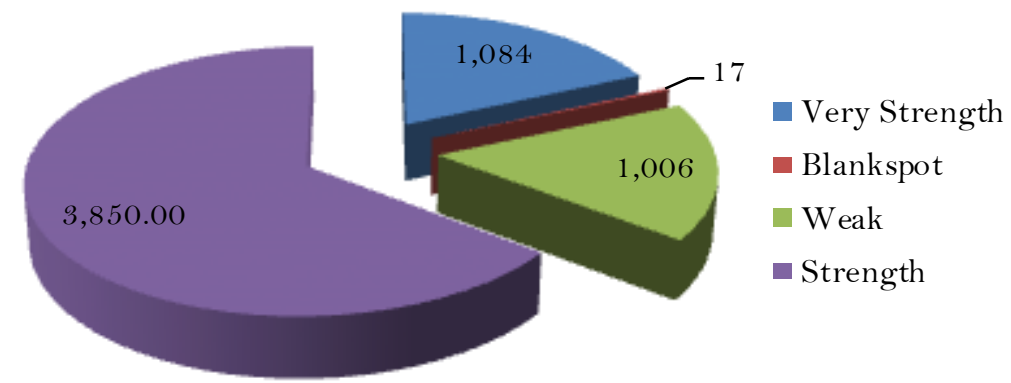

Figure 2. The proportion of cellular phone signals based on number of villages in the West Java Province in 2018 Source: https:/ / data.jabarprov.go.id data released on 13 July 2020; updated on 15 September 2020

The poor telecommunication services, especially in remote areas in West Java, is due to the limited telecommunication infrastructure, the un-optimal position of the Base Transmitter Stations, the inconsistence of signal quality, and stagnant economic growth (Virgana, 2018).

Table 1. The Distribution of Villages Without Cellular

Phone Signals Based on Regencies in West Java in 2018

\begin{tabular}{ll}
\hline REGENCY & $\begin{array}{l}\text { NUMBER OF } \\
\text { VILLAGES }\end{array}$ \\
\hline BANDUNG & 1 \\
BOGOR & 1 \\
CIANJUR & 3 \\
GARUT & 2 \\
KUNINGAN & 2 \\
MAJALENGKA & 1 \\
SUBANG & 2 \\
SUKABUMI & 2 \\
TASIKMALAYA & 3 \\
\hline TOTAL & 17 \\
\hline $\begin{array}{l}\text { Source: https://data.jabarprov.go.id } \\
\text { data released on 13 July 2020; updated on } 15 \text { September 2020 }\end{array}$
\end{tabular}

3) Internet Signal Quality

Before the Covid-19 Pandemic broke out, the national government (Ministry of Communication and Information) targeted that by 2020 all villages in Indonesia would be covered by a $4 \mathrm{G}$ internet network ("Merdeka Sinyal", 2020). At the beginning of 2020, it is 
calculated that there are only 12,548 villages remain that have not been served by $4 \mathrm{G}$ signals and are targeted to be completed by the end of the year.

In West Java province in 2018 only about half or 50 percent of villages have been covered by a $4 \mathrm{G}$ internet network. The other half: 44 percent is served by $3 \mathrm{G}$ networks and $5 \%$ served by $2 \mathrm{G}$ networks. There is still $1 \%$ (a total of sixty nine villages) that do not enjoy internet access at all (Figure.3). And again, Tasikmalaya Regency is the weakest in term of telecommunication services by having 14 villages that have not been serviced by the internet signal (Figure.4).

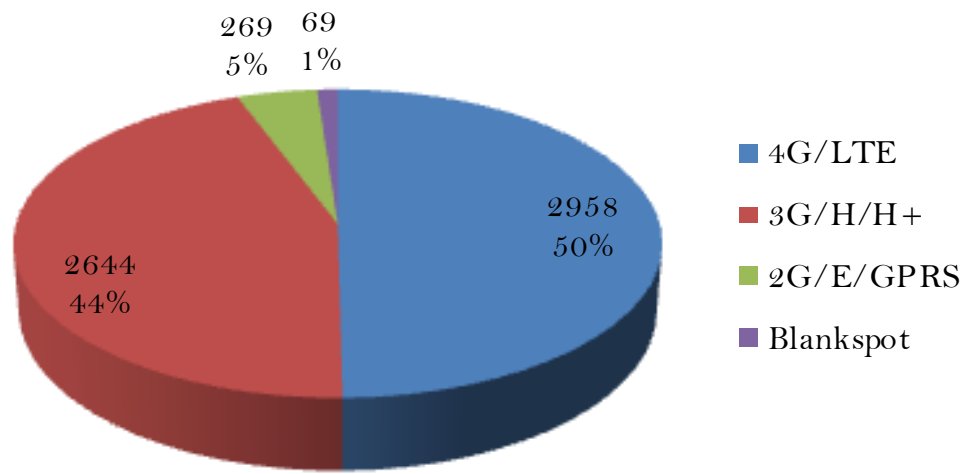

Figure 3. The proportion of internet signals quality based on number of villages in West Java Province in 2018

Sources: https:// data.jabarprov.go.id, data released on 13 July 2020, updated on 15 September 2020

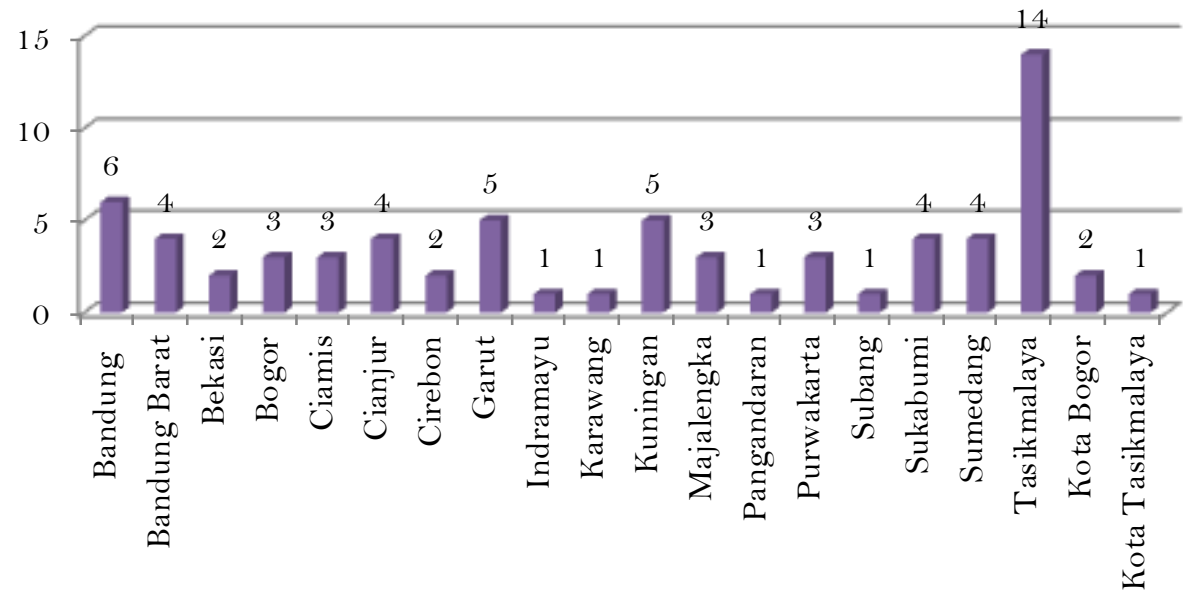

Figure.4 The distribution of villages without internet connection services in West Java Province based on Regencies and Municipalities in 2018

Source: https:// data.jabarprov.go.id; data released on 13 July 2020 and updated on 15 September 2020 
4) Base Transceiver Station (BTS)

Cellular telephone services and internet networks in an area are determined by the presence of a Base Transceiver Station (abbreviated as BTS). BTS is a tower that facilitates wireless communication. The main function of BTS is to transmit and receive radio signals and converts them to digital signals to connect mobile devices and computers with wireless connection to the network.
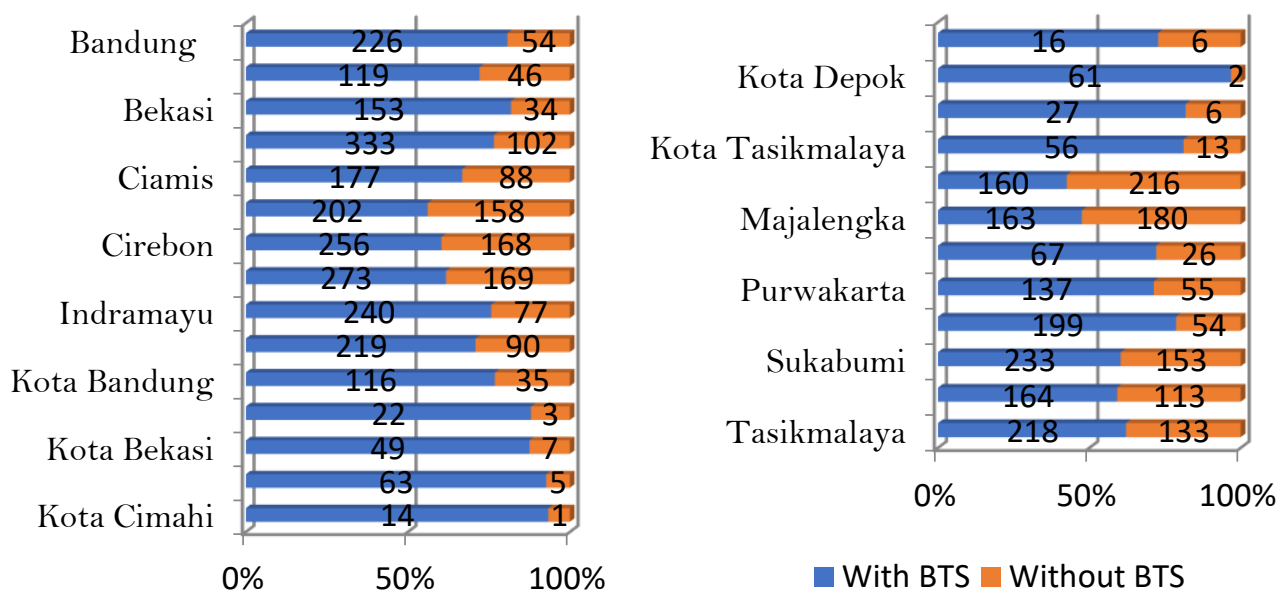

With BTS $\square$ Without BTS

Figure.5 The proportion of Villages with and without BTS in West Java Based on

Regencies and Municipalities in 2018

Sources: htttps://data.jabarprov.go.id

Data released on 13 July 2020, and updated on 15 September 2020

Figure 6 depicts the proportion of village with and without BTS tower in each Regencies and Municipalities in West Java Province in 2018. It implies the telecommunication service capacity in each territory.

However, the service of a Transmitter Station / BTS does not recognize the administrative area of a village but depends on its position on earth surface spatially (geodetic position). Virgana (2020) conducted a spatial analysis using triangulation techniques to plot GPS coverage service patern in west java in 2018 (figure.6). 


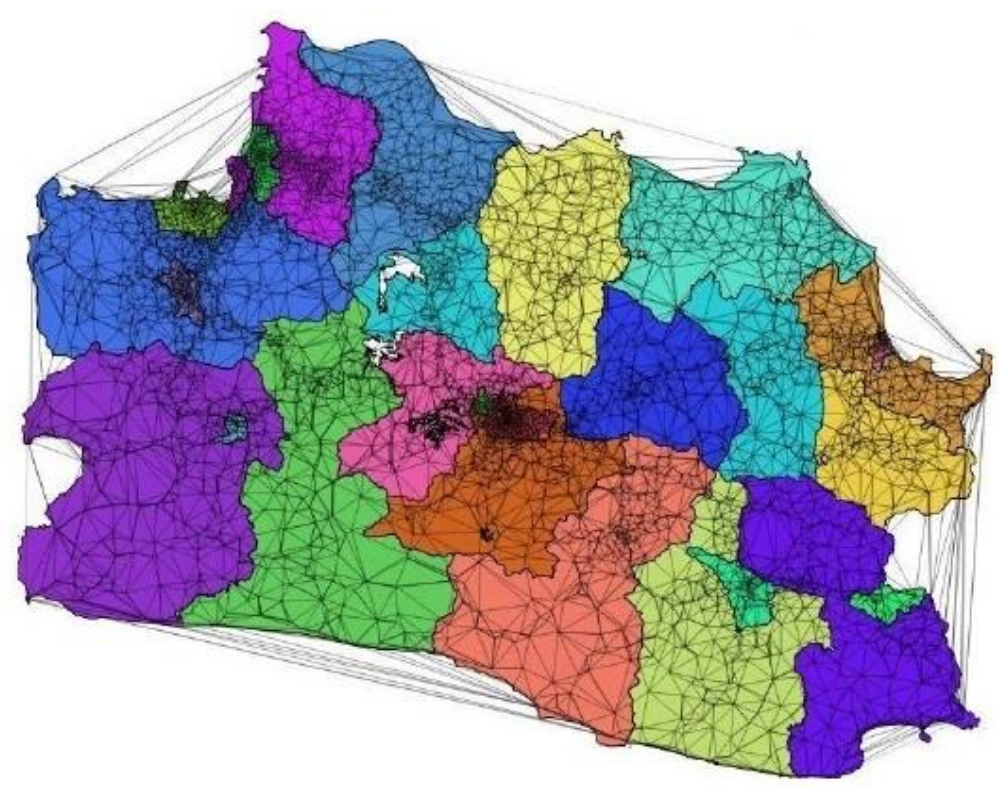

Figure. 6 The Triangulation analysis of BTS position in West Java Province, 2018 Source: Virgana (2020)

The triangulation analysis above provides an illustration that if the nets on the map are getting sporadic or less dense, the signal coverage transfered by the BTS be likely to weak. Such area has the potential to become an area without a signal or blank spot. In general, the map infers that the northern region of West Java tends to have good signal coverage compared to regencies in the southern region.

According to Virgana, the telecommunication gap in West Java is imperative to be concerned by policymakers. New regional development orientation is needed to fulfill the gap in order to achieve "Jabar Juara" as a Cyber Province.

5) ICT Development Index

The Information and Communication Technology Development Index (ICT-DI) is an indicator to monitor the development of a country or region towards an information society. It is used to monitor and compare ICT developments between regions and over time. The official institution to measure the Indonesian ICT Index at the sub-national level is Central Bureau Statistic (Badan Pusat Statistik/BPS).

According to BPS, Indonesian ICT-DI is a composite index of three sub-indices namely 1) ICT Access and Infrastructure, 2) ICT use, and 3) ICT Skills. The three sub-indices consist of eleven indicators. The first, ICT Access and infrastructure, consists of five indicators: 1) Fixed-Telephone subscriptions per 100 inhabitants; 2) Mobile-cellular telephone subscriptions per 100 inhabitants, 3) internet bandwidth (bit/s) per internet user 4) the percentage of household with computer and 5) percentage household with internet access.

The second and the third sub-indices each of them has three indicators. Indicators for ITC use sub-index are: 6) percentage individuals using the internet, 7) Fixed (wired)-broadband subscriptions and 8) Wireless-broadband subscriptions (ITC Use). And indicators for ITC 
Skills sub-index are 9) Adult literacy rate, 10) Secondary gross enrollment rate and 11) Tertiary gross enrollment rate.

ICT DI has significant and positive relationship with GDP per capita estimated by Pearson correlation. It also has a strong and positive relationship with Human Development Index (HDI), and has negative relationship with poverty (Lestariningsih, 2016).

Based on data released by BPS, West Java ICT-DI in 2017 was 5.38 (higher than the National Index 4.96). Even though as one of the capital's buffer provinces, West Java was ranked 8th nationally, below in order of 1) DKI Jakarta, 2) DI Yogyakarta, 3) East Kalimantan, 4) Bali, 5) Riau Islands, 6) North Kalimantan and 7) Banten.

In 2018, the national ICTD-DI had increased from 4.96 to 5.07. Likewise, West Java's index increased from 5.38 to 5.63 (Figure-7). Even so, the ranking of West Java was stagnant at rank 8, while the province of Banten, which was sub-region (several regencies) of West Java, rose from rank 7 in 2017 to rank 6 in 2018 past the rank of North Kalimantan province.
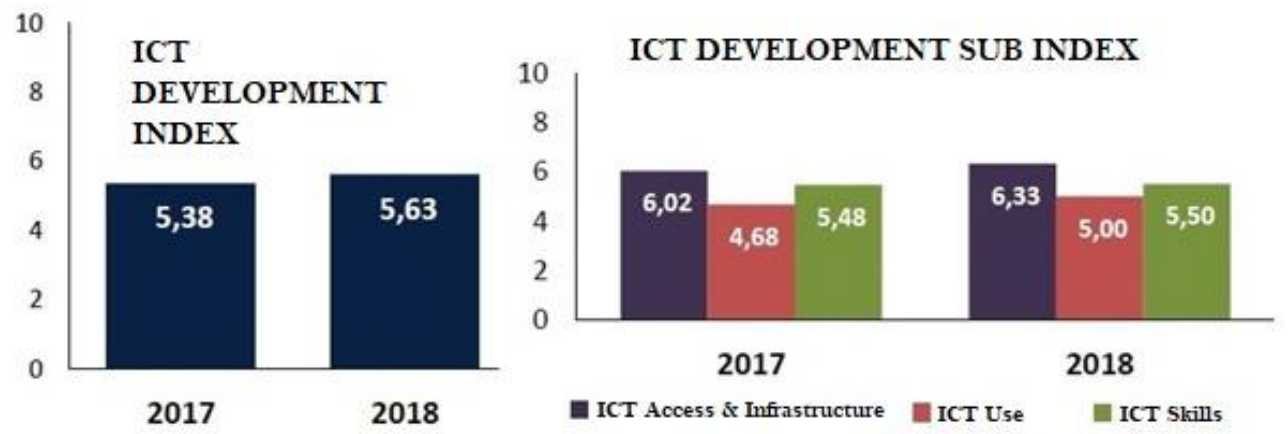

Figure. 7 ICT Development Index and Sub Indcies of West Java Province 2017 and 2018

Source: BPS, 2019

6) Information Security Index

The Internet is becoming an important need nowadays. In 2016 it was counted that Indonesia had 53,236,179 internet users, regarded as the 12th greatest population of active internet users in the world. In terms of social media activities, Indonesia is pondered highly connected and active (Islami, 2018). In 2016, Indonesia had the 4th largest Facebook user base and the 5th biggest Twitter user base in the world. Combined with the growth of the e-commerce market, these numbers alone are sufficient to underline the value of the ICT sector in Indonesia. (Rahardjo, 2020)

However, the use of the internet also has aftermaths for cybercrime threats such as copying of documents, fraud, stealing of money in bank accounts, the spread of pornographic content, hacking, buying and selling banned goods, online prostitution, etc.

Another issue is Cyberattack. In 2015 Indonesia was hit by 28,430,843 attacks and has increased to $135,672,984$ cyberattacks in 2016 (Nugraha \& Putri, 2016). Indonesia became the 10th largest country in the world with encryptor/ransomware malware infection in 2017 (Rahayu, 2018). In dealing with such issues strong cybersecurity is required. 
The government responded to the needs of national cybersecurity. In May 2017 was enacted Presidential Regulation No. 53 on the establishment of the National Cyber and Crypto Agency (Badan Siber dan Sandi Nasional/BSSN) which officially was operating in January 2018.

One of the functions of the BSSN in cybersecurity on a sub-national scale is to measure the information security index (Kemananan Informasi /KAMI) at the regency/municapality level. Refers to the Indonesian National Standard (SNI) ISO / IEC 27001, the KAMI index assessment includes Governance, Risk Management, Framework, Asset Management, Technology Aspects, and Equipment. The WE index is not intended to analyze the feasibility or effectiveness of existing forms of security, but rather as a tool to provide an overview of the readiness of an information security framework. The KAMI Index of regencies and municipalities in West Java in 2019 depicted in Figure 8.

KAMI Governence

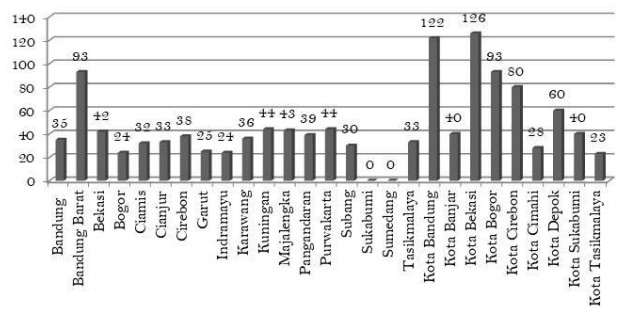

KAMI Framework

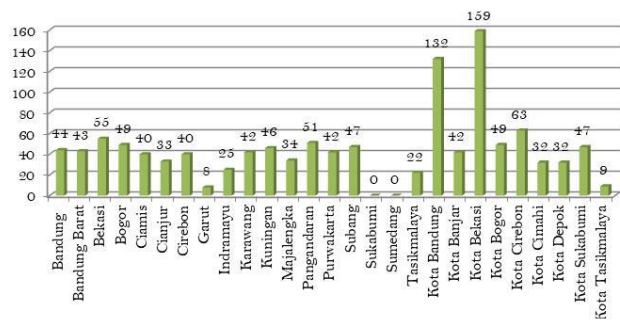

KAMI Technology Aspects

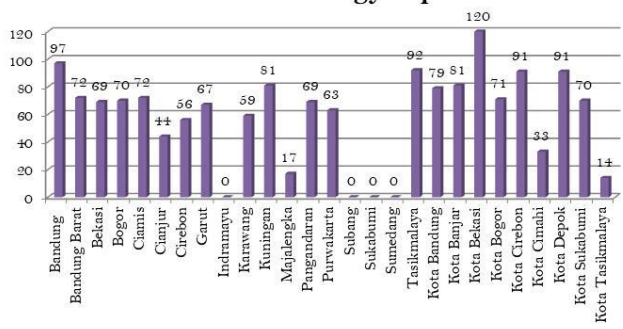

KAMI Risk Management

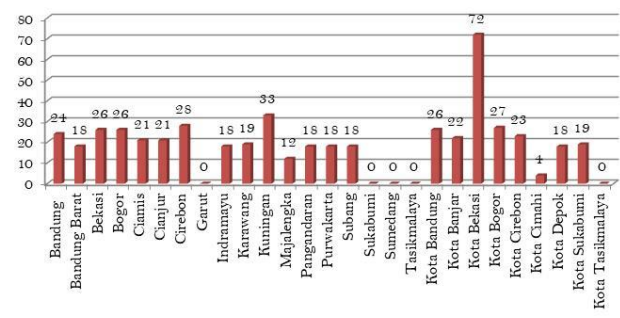

KAMI Asset Management

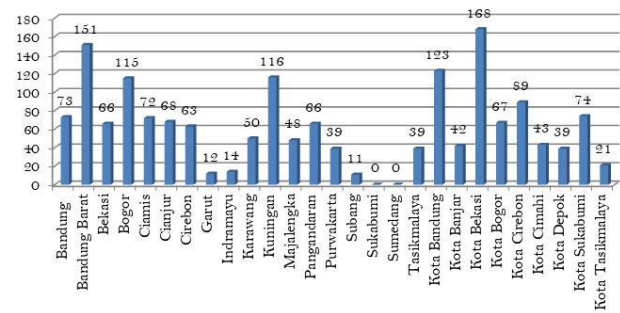

KAMI Equipment

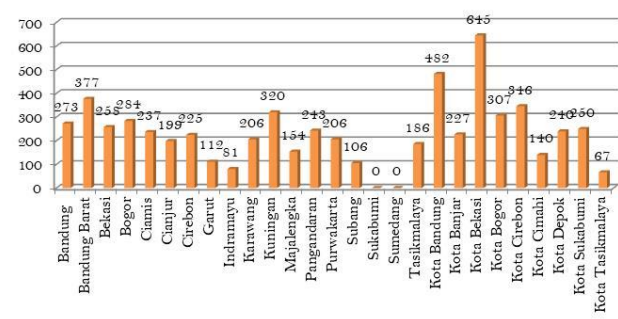

Figure. 8 KAMI Index of West Java Province Based on Regencies and Municipalities in 2019

Sources: https://data.jabarprov.go.id; data released on 25 September 2019 and updated on 16 September 2020

\subsection{The new orientation of West Java Development Planning}

At the time this paper was written, the Covid-19 pandemic was not over yet. On the other hand, the daily positive case rate has continued to increase to around 4 thousand positive 
cases per day in the last weeks. However, on July 20, 2020, the government made a policy breakthrough through Presidential Regulation (Peraturan Presiden/Perpres) Number 82 of 2020 concerning the Committee for Handling Covid-19 and the National Economic Recovery. With this Perpres, the government revokes Presidential Decree number 9 of 2020 concerning Amendments to Presidential Decree number 6 of 2020 concerning the Task Force for the Acceleration of Handling Covid-19 and replaces it with a committee that integrates the task of health recovery with economic recovery.

To enrich the references/literature on economic recovery efforts, especially in the aspects of regional development planning, this paper contributes to predicting post-pandemic development orientation. The prediction of this paper includes 1) the Education sector, 2) Infrastructure, and 3) Public service bureaucracy. The predictions of these three sectors are constructed in Information and Communication Technology (ICT) development logical framework.

\subsubsection{Education Sector}

The impact of the pandemic on the education sector has been significantly undergone. Due to social distancing policies, the conventional (classical) learning methods cannot be applied. Although distance learning is planned to only be implemented until December 2020, the Minister of Education emphasized that the virtual learning process using information technology has become a global trend (Putra, 2020). The blended learning method using information technology will be potentially promoted after the pandemic in order to improve the quality of national education.

Academics infer that the pandemic has been accelerating the transformation of education towards digitalization but requires a systemization of the academic curriculum (Karim, 2020). The others argued that the flexible curriculum is a way out for learning during the Covid-19 period (Gusty, et al, 2020). Correspondingly, the concept of "Merdeka Belajar" (independent learning) offered by the Minister emphasizes the self-determining of the students and parents in defining the best way in the learning process.

Before the pandemic outbreak, some citizens who pay attention to education have contributed to the community by sharing knowledge through information technology. For example, in 2107 an Indonesian start-up company that focuses on education initiated www.ruangguru.com, a school curriculum-based learning platform through interactive video tutorials and animation presented by teachers which are accessed on mobile phone and computer applications. In 2019 this page has 15 million subscribers.

In terms of enhancing the life skills of the young generation, Indonesian millennials have collaborating to create the http://prakerja.org. Created as constructive criticism of government programs, this platform provides entrepreneurship training containing business ideas, self-development, business and finance, technology and software, and digital business. All services provided are free.

The substance of all these phenomena is that the community is increasingly being independent in gaining knowledge, developing expertise, and improving skills. The minister's concept of "Merdeka Belajar" is very relevant to the current world circumstances.

Before the pandemic forced school from home to be applied in Indonesia (and in almost all countries), some parents prefer homeschooling as the choice for their children. It is not only 
opting for young artists, young athletes, children of diplomats who frequently move across countries, or children with special needs; homeschooling is also adopted by ordinary children from the middle class, especially in big cities such as Bandung, Bogor, and Depok. Homeschooling children are educated directly at home by their parents either independently or through institutions or umbrella schools.

Furthermore, exclusive educational institutions such as athlete schools, and some religious education institutions such as Islamic boarding schools, Ma'had, Al-Quran Tahfidz Institute, and Bible Schools; develop their own educational curriculum for their students. To meet the formal requirements, both homeschoolers (children who receive home education) and participants of exclusive education institutions take the extramural exam of Package A, B, and $\mathrm{C}$ as equalization lines.

Independent homeschooling communities usually consult with the Regency/City Education Office in particular with the Extramural Education Department. They need facilitation especially in the legality aspect and in pursuing the equality program. Based on the author's observation, there are still a few Education Offices in West Java that intensely assist the homeschooling community, one of which the Bandung City Education Office. Some of the homeschoolers in West Java take the extramural exam outside the province territory as they received more cooperative services from the local education office.

Some of the future education sector outlooks are: relevant to the concept of Merdeka Belajar, the homeschooling community will receive additional regulatory support. The Center of Teaching and Learning Activities (Pusat Kegiatan Belajar Mengajar /PKBM) as an official forum fostered by the Extramural Education Department at the regencies/municipalities Education Office will have an increasingly important role. It is projected that the future curriculum will be more flexible. Teachers will be more required to master audiovisual media. The subject matter will be digitized either in the form of text in pdf format or in the form of video recordings that students can download before or after class hours. The Special Allocation Fund (Dana Alokasi Khusus / DAK) for Education which was mainly for school construction or rehabilitation of new classrooms is projected to be shifted for telecommunication facilities and infrastructure. Predictions about the orientation of infrastructure development are discussed in the next section.

\subsubsection{Infrastructure}

The Covid-19 pandemic disrupts national infrastructure projects such as delays in moving the new nation's capital to Kalimantan (Anggraeni, 2020), delays in the construction of MRT Phase 2 in DKI Jakarta (Umasugi 2020), and unclear follow-up on the Jakarta-Bandung fast train project (Winarto, 2020). The economic recession that has befallen developed countries as investors and the unfinished research to find a Covid-19 vaccine adds to the uncertainty of infrastructure development plans in Indonesia.

A similar situation occurred in regional infrastructure development in West Java. The budget for road construction at Dinas Binamarga in the 2020 fiscal year leaving only 23,9 percent of the total local budget due to refocused on handling Covid-19. Initially, in 2020 there should be around 90 infrastructure project procurement packages, but only around six packages will be realized. The provincial road maintenance project, which was targeted at $88.59 \mathrm{~km}$ long, corrected to only $3.1 \mathrm{~km}$. The Cisumdawu Toll Road and Cigatas Toll Road 
Projects are delayed from the initial plan. Likewise, the work on the Al-Jabar Mosque, which should have been completed in 2020, has delayed its completion (Ramadhan, 2020).

The prediction of future infrastructure development will be oriented towards telecommunication infrastructure development. Although the authority to develop energy and telecommunication infrastructure, in general, is the authority of the national government (ministries) with State-Owned Enterprise (Badan Usaha Milik Negara/BUMN) operators (such as PT. PLN and PT. Indonesia Power for the energy sector, and PT. Telkom for the telecommunications sector), the Provincial and Regency / Municipality Governments still have a significant role. The Regional Government can play a role in proposing and endorsing that with a huge population of West Java as well as potential customers, the return on investment in West Java is attractive and prospective.

In line with the approval of the Omnibus Law on the Job Creation, it is projected that the authority of the Provincial and Regency/Municipality Governments will decrease. For example, permits related to spatial planning and environmental permits within Environmental Impact Analysis (Analisis Mengenai Dampak Lingkungan/AMDAL) documents and other environmental documents will become the authority of the central government. Thus, local governments are projected to tend to be just beneficiaries of strategic developments.

The post-pandemic regional development orientation related to energy is to fill the remaining niches/gaps. For example, for energy provision in remote areas, the construction of a Micro Hydro Power Plant (Pembangkit Listrik Tenaga Mikro Hidro/PLTMH) can be an attractive core business for Local Government-Owned Enterprise (Badan Usaha Milik Daerah/BUMD). The experience of PT Tirta Gemah Ripah as a West Java's BUMD in building and operating PLTMH in Cirompang, Garut Regency is a success story that can be developed in the future. The low electrification ratio and the abundance of water resources and rivers with a steep topography in southern West Java can pose BUMD business challenges and opportunities in the future.

In the telecommunications sector, local governments have a similar role. Local governments can bridge cooperation between internet service providers (ISPs) and village-owned enterprises (BUMDES) in providing sustainable internet services in remote areas. In addition to being a bridge for Cooperation Agreements (Perjanjian Kerja Sama /PKS) Business to Business (B to B) for paid internet services for rural customers, local governments can also encourage the use of Village Funds for free internet access (WI-FI) for their residents. Prediction of future use of the Village Fund (Dana Desa) will not only for the construction of village roads, neighborhood roads, or other physical buildings but will be oriented towards telecommunications infrastructure. This development orientation is positive in supporting community activities in education. Internet infrastructure can also support the Tourism Village development program (Pengembangan Desa Wisata). The number of tourists will increase if internet access is available in every village tourism object so that it can increase the village's revenue (Pendapatan Asli Desa) and improve the economy of the village community. 


\subsubsection{Public Service Bureaucracy}

Before the pandemic outbreak, the National Development Planning Agency (BAPPENAS) had already applied flexible work and time for the particular State Civil Apparatus (Aparatur Sipil Negara / ASN) at the beginning of 2020. Mungkasa (2020) posits that the technology for 'working from home' has been ready for a long time, but society and the bureaucracy who are bound to a business as usual pattern tend to disregard the chance to use it. Covid-19 helps implement working from home system.

Refocusing the government budget in the second quarter of the 2020 fiscal year changes the posture of state spending to emphasize handling covid-19. The budget for civil servant's business trip and government meetings was trimmed with work from home rules and virtual meetings in accordance with the Minister of Empowerment of the States Apparatus and Bureaucratic Reform Circular (SE MenPAN-RB) number 19 of 2020. Public services are being transformed towards digitalization.

Digital transformation in public service from manually face-to-face services to virtual deviceto-device services continues to experience a significant increase during the Covid-19 period. Not only for civil services such as application for birth certificates, family cards, extension of driving licenses, and payment of annual vehicle taxes, computer-based applications are also used in daily apparatus activities such as employee attendance, meetings, and monitoring and evaluation of work performance. Personal digital literacy of civil servants has also increased whereas previously they relied on specialists in the office.

However, in terms of budget efficiency, the government faces two conflicting policy bearings. After Presidential Decree No. 82/2020 was published, the orientation of economic recovery tended to be more prominent than health recovery. Although social restriction (PSBB) are still in place, Civil servant business trip with hotel accommodation as common as before the pandemic outbreak. Conventional government meetings in hotels are being held more frequently.

Purposing to foster the air transportation industry and tourism sector, through a circular letter, a Coordinating Minister has persuaded the ministries under its coordination to accelerate the budget absorption of public servant business trip as well as encouraging ministries to conduct national government meeting at national main tourism objects such as Bali, Lombok, and Batam. In September 2020, several mass media reported that one of the main national tourism objects was reviving and the occupancy rate of hotel accommodation increased after government meeting activities were held at that place.

Those such ambiguous policies tend to be repeated and became an odd phenomenon in terms of the concept of efficiency. For example, in early 2015 the newly appointed MenPAN-RB made a breakthrough in its 100-day program by issuing a prohibition policy for ASN meetings in hotels and consuming imported food. It was considered adequate for government officials' meetings to be held in offices and meals served with modest local foods such as sweet potatoes and cassava. This populist policy with a spirit of minimalist lifestyle and efficient living turned out to be objected to by the hospitality industry so that it only lasted for several months.

The perspective on the efficiency of public sector activities may differ to some extent from the perspective of the private sector (business). The first prioritizes benefits for the 
community, while the latter emphasizes profits for the corporation. Inefficient government expenditure tends to occur also in developed countries. In Japan, based on author observation, road reconstruction projects could be carried out on road in good condition. Such uneconomical policy was opted not to improve services to road users, but merely to run the construction industry, which is one of the sectors that is protected as it is one of the nation's core competences.

Post-pandemic public service bureaucracy outlooks still on the pros and cons of the efficiency concept. Policymakers are still pursuing an ideal concept regarding bureaucratic reform. Debureaucratization for the sake efficiency through dismemberment echelon III and echelon IV which has implemented in ministries and national institutions, will meet reluctance from sub-national institutions. Government spending, which in economic theory has a multiplier effect in increasing GDP as it creates demand for goods and services (consumption) will be a contra argument for hopes of efficiency in the public sector.

The other global trend in the post-pandemic era is the concept of e-government. The application of e-planning, e-budgeting, and alike will be adopted entirely by all regencies and municipalities in the West Java province. Nowadays in several cities and municipalities, civil service products such as birth certificates and family cards can be downloaded and printed by residents themselves. In the future, such public service conduct will be a conditio sin qua non in all local government in West Java province.

\section{Conclussion}

From the discussion above, it can be concluded as follows:

1. Government policy in dealing with the impact of the Covid-19 pandemic is a moderate mode or combination between health recovery and economic recovery. The moderate path taken continues to have an impact on the economy, socio, culture, education, development planning, and public services. The limitation of social activities forces people to adapt to new habits that rely on long-distance communication (telecommunications) and activities on the internet (online) network. This new habit requires adequate infrastructure support, so that the demand for the provision of telecommunications infrastructure increases during and after the pandemic.

2. The existing condition of Information and Communication Technology (ICT) infrastructure in West Java is marked by significant disparities between the northern and southern regions, especially in terms of 1) electrical energy infrastructure, 2) cellular signal strength, and 3) internet signal quality. This disparity needs to be aware by stakeholders so that the West Java ICT Development Index, which nationally remains at rank 8 (in 2017 and 2018), increases in the future so that it can win West Java Champion and as a cyber province.

3. The post-pandemic Development orientation in West Java province includes:

a) In the education sector, the Regency/Municipality Education Office is predicted will revitalize the Extramural Education Department to respond to the concept of "Merdeka Belajar" from the Ministry of Education and Culture and to respond to the development of community independence in education as ICT advances; 
b) In infrastructure development, Provincial and Regency/Municipality Governments are predicted tend to be just beneficiaries of strategic infrastructure development projects conducted by the central government and operated by BUMN. Therefore, local government should be able to fill the gaps such as the opportunity to build PLTMH by BUMD and facilitating the provision of internet access in remote areas;

c) The covid-19 pandemic has accelerated the realization of e-government and the Internet of Things behavior in West Java, however, the concept of efficiency in bureaucratic reform will continue to pursue its ideal form.

\section{References}

Anggraeni, R (2020, September 8). Pembangunan Proyek Ibu Kota Baru Resmi Ditunda, okezone.com, retrived from https://economy.okezone.com

Dewan TIK Nasional (2020), Less Physical Contact Economy, Atasi Pandemi Covid-19 Selamatkan Ekonomi, Buletin Bulanan, Edisi Juni 2020, Tim Humas Wantiknas, Jakarta.

Gusty, S., Nurmiati, N., Muliana, M., Sulaiman, O. K., Ginantra, N. L. W. S. R., Manuhutu, M. A., ... \& Hastuti, P. (2020). Belajar Mandiri: Pembelajaran Daring di Tengah Pandemi Covid-19. Yayasan Kita Menulis.

Islami, M. J. (2018). Tantangan Dalam Implementasi Strategi Keamanan Siber Nasional Indonesia Ditinjau Dari Penilaian Global Cybersecurity Index. Masyarakat Telematika Dan Informasi: Jurnal Penelitian Teknologi Informasi dan Komunikasi, 8(2), 137-144

Karim, B. A. (2020). Pendidikan Perguruan Tinggi Era 4.0 Dalam Pandemi Covid-19 (Refleksi Sosiologis). Education and Learning Journal, 1(2), 102-112.

Maqin, A. (2014). Pengaruh Kondisi infrastruktur terhadap pertumbuhan ekonomi di jawa barat. Trikonomika Journal, 10(1), 10-18.

Merdeka Sinyal hingga Pelosok Negeri, (2020, August 3), Indonesia.go.id. retrived from https://indonesia.go.id.

Mungkasa, O. (2020). Bekerja dari Rumah (Working From Home/WFH): Menuju Tatanan Baru Era Pandemi COVID 19. The Indonesian Journal of Development Planning, 4(2), 126-150.

Nugraha, L. K., \& Putri, D. A. (2016). Mapping the Cyber Policy Landscape: Indonesia. Global Partners Digital, 1-28.

Nugroho, R., Suprapto, F. A., Widiastuti, I., \& Firdausy, E. F. (2020). Evaluasi Kebijakan Respon Pandemi Covid 19. Rumah Reformasi Kebijakan [Institute for Policy Reform].Jakarta.

Pembelajaran jarak jauh disdik jabar akui tantangan terbesar adalah akses internet, (2020, June 3), penaku.id. retrived from https://penaku.id

Pradesha, A., Amaliah, S., Noegroho, A., \& Thurlow, J. (2020). The cost of COVID-19 on the Indonesian economy: A Social Accounting Matrix (SAM) multiplier approach. Intl Food Policy Res Inst.

Putra,I.P (2020). Kemendikbud Meluruskan Makna 'PJJ Permanen, medcom.id, retrived from https://www.medcom.id 
Rahardjo, B. (2018). The State of Cybersecurity in Indonesia. Digital Indonesia: Connectivity and Divergence.

Rahayu, D. (2018, August). Indonesia National Cybersecurity Review: Before and After Establishment National Cyber and Crypto Agency (BSSN). In 2018 6th International Conference on Cyber and IT Service Management (CITSM) (pp. 1-6). IEEE.

Rahmad Rahim. (2020). Penguatan Peran Rencana Kerja Pemerintah Daerah (RKPD) untuk Menghadapi Pandemi Covid-19. Majalah Media Perencana, 1(1), 33-61. Retrieved from

Ramadhan, B. (2020, June 24). Sejumlah Proyek Infrastruktur Jabar Ditunda Karena Covid19. Republika.co.id. Retrived from https://republika.co.id

Republik Indonesia, 2004, Undang-Undang Republik Indonesia Nomor 25 Tahun 2004 Tentang Sistem Perencanaan Pembangunan Nasional, Lembaran Negara Republik Indonesia Tahun 2004 Nomor 104, Sekretariat Negara, Jakarta.

Republik Indonesia, 2020, Keputusan Presiden Republik Indonesia Nomor 7 Tahun 2020 tentang Gugus Tugas Percepatan Penanganan Corona Virus Disease 2019 (Covid-19), Sekretariat Kepresidenan Repubik Indonesia, Jakarta.

Republik Indonesia, 2020, Keputusan Presiden Nomor 12 tentang Penetapan Bencana Non Alam Penyebaran Corona Virus Disease 2019 (Covid-19) Sebagai Bencana Nasional, Sekretariat Negara Repubik Indonesia, Jakarta.

Republik Indonesia, 2020, Peraturan Pemerintah nomor 21 tahun 2020 tentang Pembatasan Sosial Bersekala Besar Dalam Rangka Percepatan Penanganan Corona Virus Disease 2019 (Covid-19), Lembaran Negara Republik Indonesia Tahun 2020 Nomor 91, Tambahan Lembaran Negara Republik Indonesia Nomor 6487, Sekretariat Negara, Jakarta.

Republik Indonesia, 2020, Peraturan Presiden Nomor 82 Tahun 2020 tentang Komite Penanganan Covid-19 dan Pemulilhan Ekonomi Nasional, Sekretariat Kepresidenan, Jakarta.

Republik Indonesia, 2020, Surat Edaran Menteri Pendidian dan Kebudayaan Republik Indonesia Nomor 4 tahun 2020 tentang Pelaksanaan Kebijakan Pendidikan Dalam Masa Darurat Penyebaran Corona Virus Disease (Covid-19), Sekretariat Jenderal, Jakarta.

Republik Indonesia, 2020, Surat Edaran Menteri Pendayaan Aparatur Negara dan Reformasi Birokrasi Nomor 19 Tahun 2020 tentang Penyesuaian Sistem Kerja Aparatur Sipil

Negara Dalam Upaya Pencegahan Penyebaran Covid-19 di Lingkungan Instansi Pemerintah, Sekretariat Jenderal, Jakarta.

Sugiono. (2009). Metode Penelitian Kualitatif dan R\&D. Alfabeta. Bandung.

Taufik, T., \& Warsono, H. (2020). Birokrasi Baru Untuk New Normal: Tinjauan Model Perubahan Birokrasi Dalam Pelayanan Publik Di Era Covid-19. Dialogue: Jurnal Ilmu Administrasi Publik, 2(1), 1-18.

Theodora. A, Saptowalyono.C.A, Judith.P.M (2020), Kebangkitan Ekonomi dari Rumah Hadapi Paradoks, kompas.com, retrived from: http://kompas.com

Umasugi, A.R (2020, October 19). Ini Penyebab Proyek MRT Jakarta Fase 2Terancan Diundur, kompas.com retrived from https://megapolitan.kompas.com

UN DESA. (2020). World Social Report 2020: Inequality in a Rapidly Changing World.

Verma, A., \& Prakash, S. (2020). Impact of covid-19 on environment and society. Journal of Global Biosciences, 9(5), 7352-7363. 
Virgana, R. A. E. (2018, January). Membangun Awareness Kesenjangan Telekomunikasi Pedesaan di Jawa Barat Dengan GIS Analysis for ICT Blank Spot Area menuju Jabar Cyber Province. In Prosiding-Seminar Nasional Teknik Elektro UIN Sunan Gunung Djati Bandung (pp. 10-17).

Wahyudi, A. T., Suparti, E., \& Wicaksana, B. I. A. Solusi IoT untuk adaptasi New Normal. Jurnal Ilmiah Teknik Industri dan Informasi, 2(8):99-109.

Winarto, Y. (2020, April 15). Luhut: Proyek kereta cepat Jakarta-Bandung tertunda garagara corona (covid-19). Kontan.co,id. Retrived from https://industri.kontan.co.id 